\title{
大雪山国立公園トムラウシ山における登山者のルート選択要因
}

\section{Factors Influencing Route Selection by Visitors to Mt. Tomuraushi, Daisetsuzan National Park}

\author{
愛甲 哲也** 川口 恵典**
}

\section{Tetsuya AIKOH Keisuke KAWAGUCHI}

\begin{abstract}
Knowing the factors considered by hikers in selecting their entrance and routes can be helpful for mountainous natural park managers. Mt. Tomuraushi in Daisetsuzan National Park used to be a remote destination that required hikers to make overnight trips to reach the summit. With easier access, there has been a recent increase in day trip hikers. This increase has raised certain concerns, such as soil erosion on the visitor trails, trampling of vegetation, and extension of bare grounds around campsites. We conducted questionnaire survey on hikers' route selection and their reasons for choosing a specific route and trailhead to Mt. Tomuraushi. The results showed that hikers placed much value on scenery, availability of natural resources, and access and convenience of each route and trailhead. Important factors included conveniences, walkability and good scenery. More experienced hikers were found to be more likely to choose less convenient and less crowded trailheads than less experienced hikers.
\end{abstract}

Keywords: National Park, choice, route, crowding, experience, convenience キーワード：国立公園，選択，ルート，混雑，体験，利便性

\section{1. はじめに}

登山者は様々な要因を考慮してその行動を決定しており，登山 者が考慮する要因の把握は適正な利用の誘導に有用である。 Lucas（1990）は，米国のウィルダネスエリアで，登山口と野営 地の決定に, 旅行の長さや過去の経験, 準備期間, 孤独を求める 欲求，目新しさ，熟知度などが関与することを示した 6)。国内で は，小林（1999）が大雪山国立公園の登山者の目的地の選択決定 に自然環境や景観が重視されること5)，河井(2008)が南アルプス 南部で山小屋の配置間隔がルートの選択に影響寸ること 4)，山本 (2010)が富士山において混雑を回避して登山口やルートを選択す る登山者が存在することを明らかにしている 11)。庄子ら（2005） は選択型実験を用いて歩行時間や旅行費用，紅葉，混雑の状況が 登山者の選択行動に影響することを示した 8)。山本(2011)は，富 士山の異なる登山口ごとで登山者の属性や満足度も異なることを 示しており 12), 選択の結果は登山者の事後評価にも影響すること が考えられる。そのため, 登山者がじのような要因を重視して, 登山口やルートを選択しているかは，より適切な利用者の選択や 行動を誘導する際に有用な情報となる。

大雪山国立公園のトムラウシ山は，かつては数泊の宿泊を伴わ なければ登頂できず，「遥かな山」と呼ばれる奥深い山だった。し かし，林道と駐車場の整備によりアクセスが改善され，日帰りの 登山者が増加した。さらに, 道央圈からの距離が最も短い新たな 登山口が知られるようになり，登山者が増えつつある 2)。トムラ ウシ山本来の魅力であった原始的な自然環境が変化しつつあり， 利用者である登山者の動態・意識の把握に基づいた適正な対策が 望まれている。

本研究では大雪山国立公園卜ムラウシ山を対象に, 登山者がル 一トを選択する要因を明らかにすることを目的に意識調査を行っ た。実際のルートの選択と属性，ルートを選択する際に重視され た要因との関連を分析した。

\section{2. 調査地および方法}

トムラウシ山 $(2,141 \mathrm{~m})$ 几登頂するには, 複数のルートが存 在する (図 - 1)。最も利用者が多いと言われているのがトムラウ シ温泉からトムラウシ山へ登山するルートである。かつては，表 大雪および十勝連峰からの縦走路上にある山で, トムラウシ温泉 まで車道が開設されたのは 1960 年代であった。さらに, 1980 年 代にトムラウシ温泉の奥に林道が開設され，短縮登山口として利 用されるようになり急速にアクセスが容易となり, 日帰りでの卜 ムラウシ登山が可能となった。現在, 公園計画に定められた歩道 の中では唯一, 日带りでの往復が可能なルートである。しかし, 往復で 10 時間以上を要し, 山頂付近の気象条件は厳しいため, 2009 年 7 月の大規模な遭難事故をはじめ, たびたび遭難や事故が 発生している。その他の天人峡，クチャンベッ， ヌプントムラウ シからはいずれも行程が長く途中での宿泊を要する。また，トム

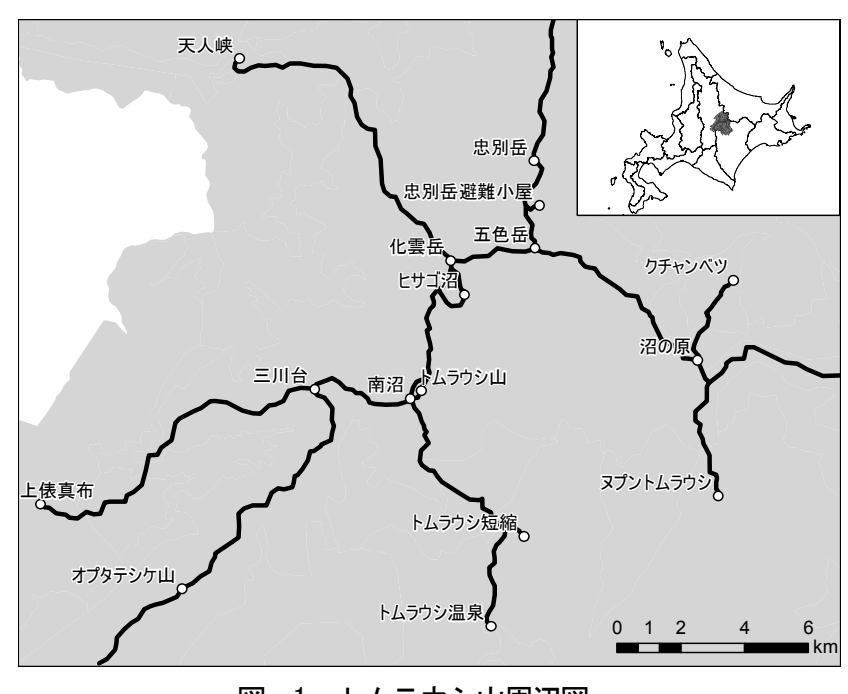

図一 1 トムラウシ山周辺図

*北海道大学大学院農学研究院 ${ }^{* N} N P 0$ 法人南アルプス研究会 
ラウシ山は，表大雪から忠別岳を経て，オプタテシケ山から十勝 連峰へ向から縦走路，トムラウシ温泉から表大雪または沼の原を 経て石狩岳方面へ至る縦走路の交差地点でもある。さらに近年に なって，上俵真布から三川台を経て，トムラウシ山にいたるルー トが，全体的に緩やかで登りやすく，道央圈からのアクセスもよ いという理由で登山されるようになった。廃道となっていたルー トが 1992 年に遭難救助用として再生され，スポーツ新聞やイン ターネット上で紹介されたことで一般にも知られるようになった。 ただし，入山には森林管理署で入林許可を得て，林道の鍵を借り る必要がある。入林許可の手続きは平日の日中に限られ, 鍵の数 も限定されているため，入山者数は一定に制限されているが，公 園計画に定められていない歩道の一般開放には関係者の間に異論 もある。北海道内で発行されているガイドブックには, 現在も避 難用経路として紹介されている（梅沢・菅原，2004）9）。

意識調査は, トムラウシ山の登山者を対象に行った。各登山口 を利用する登山者に調査票を配布するため, 山頂および南沼野営 指定地, また主要な登山口（トムラウシ温泉・短縮, 上俵真布, 天人峡）と山頂の間において調査票を配布し，郵送で返答を依頼 した。調查は 2005 年 7 月 9 月に実施し, 835 人に調查票を配 布し, 475 人から有効回答を得た。有効回答率は $56.9 \%$ であった。

質問項目のうち，登山については，日程，人数，入山・下山場 所を質問した。回答者がトムラウシ山への登山ルートを決定する 際に重視した要因については, 登山口と登山ルート上, 宿泊地の 施設整備度合いや歩きやすさ，ルートの眺望や自然性，他の登山 者数などの 21 項目について, 1 : 全く重視しなかった〜 5 : と ても重視した，の5段階で質問した。さらに，性別，年代，トム ラウシ山への登山回数，大雪山への来訪回数について質問した。

回答者は，男性が $61.3 \%$, 年代は「50 代」(37.1\%) が多く, 次いで「60 代」 $(32 \%) ， 「 40$ 代」(14.3\%) だった。トムラウシ 山の登山回数は, 1 回目が最も多く $(63.8 \%)$, 次いで $2 \sim 3$ 回目 $(20 \%) ， 4$ 回以上 $(15.8 \%)$ だった。大雪山への来訪回数を質問 したところ，11 回目以上が最も多く $(26.9 \%)$, 次いで 4 10 回 目 $(25.9 \%), 2 \sim 3$ 回目 $(23.8 \%), 1$ 回目 $(19.4 \%)$ だった。

\section{3. 結果}

\section{（1）登山ルートと属性}

入山場所は, トムラウシ温泉・短縮が最も多く挙げられ (62.7\%), 続いて上俵真布, 旭岳温泉, クチャンベツとなった（表 - 1)。下
山場所は, トムラウシ温泉・短縮が最も多く $(77.0 \%)$, 続いて上 俵真布, 天人峡, クチャンベッであった。ルートを, 入山場所と 下山場所の組み合わせからみると, トムラウシ温泉・短縮の往復 (以下，トムラウシ往復）が最も多く $(61.7 \%)$, 次いでトムラウ シ温泉・短縮から入山し他の登山口に下山，または他の登山口か らトムラウシ温泉・短縮に下山（以下，トムラウシどちらか）が $(15.8 \%)$, 上俵真布から入山し他に下山，または他から入山儿上 俵真布に下山（以下，上俵真布どちらか）が (8.8\%) で, その他 は $13.7 \%$ たた。グループの人数は， 2 人が最も多く $(29.9 \%)$, 3 人 6 人 $(26.8 \%), 7$ 人以上 $(24.9 \%), 1$ 人は $(18.4 \%)$ だっ た。山中での宿泊は，半数以上は日帰り $(54.7 \%)$ 。テント泊 $(25.3 \%)$ ，山小屋とテントの併用（13.7\%）が続き，山小屋のみ の利用は少なかった $(6.3 \%)$ 。

選択されたルートと属性の関連をみると (表 - 2), 性別, 住所, 人数, 日数, トムラウシ山の登山経験, 大雪山全体の登山経験と

表- 1 登山口とルート

\begin{tabular}{llrr}
\hline 項目 & 登山口・ルート & 度数 & $\%$ \\
\hline 入山場所 & トムラウシ温泉 & 298 & 62.7 \\
& 上俵真布 & 39 & 8.2 \\
& 旭岳温泉 & 34 & 7.2 \\
& クチジッ & 31 & 6.5 \\
& 層雲峡温泉 & 21 & 4.4 \\
& 人峡 & 17 & 3.6 \\
& その他 & 35 & 7.4 \\
\hline 下山場所 & トムラウシ温泉 & 363 & 76.4 \\
& 上俵真布 & 37 & 7.8 \\
& 天人峡 & 28 & 5.9 \\
& クチャンベッ & 22 & 4.6 \\
その他 & 25 & 5.3 \\
\hline ルート トムラウシ往復 & 293 & 61.7 \\
& トムラウジ & 75 & 15.8 \\
& 上俵真布どちらか & 42 & 8.8 \\
& その他 & 65 & 13.7 \\
\hline
\end{tabular}

表- 2 ルートと属性の関連（カイ2 乗検定）

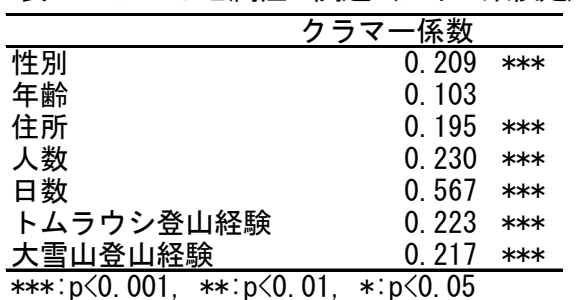

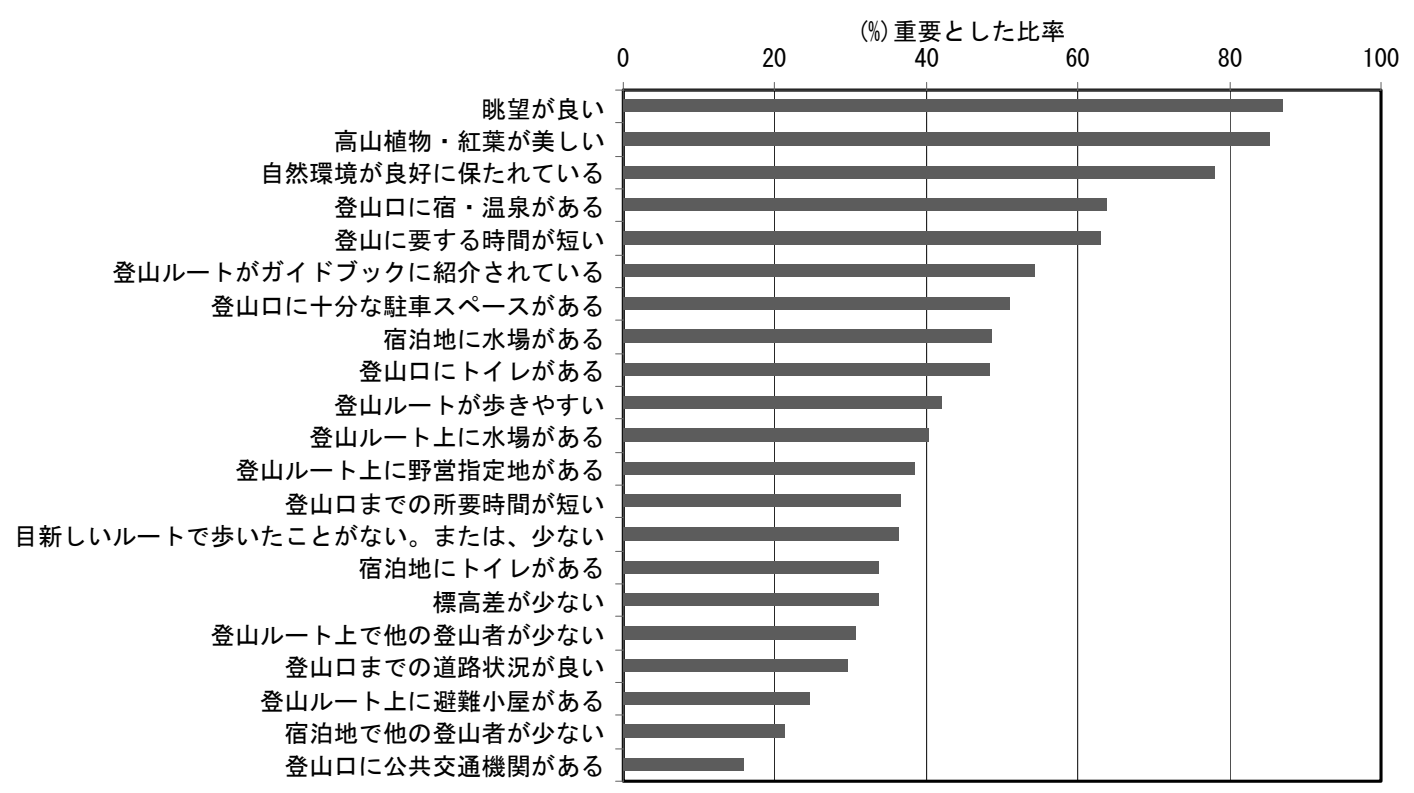

図－２ルートの選択要因 
有意な関連がみられた。性別では，男性にややトムラウシ往復が 多かった。住所では，北海道内在住者で上俵真布どちらかが多か った。人数では, 6 人以上のグループは大半がトムラウシ往復で あり，3-5人のグループで上俵真布やその他の登山口を選ぶも のが多かった。日数では, 日帰り登山者はほとんどがトムラウシ 往復であり，1泊の登山者は上俵真布が多く，2泊以上の登山者 はその他の登山口が多かった。トムラウシ山と大雪山の登山経験 のいずれにおいても，経験が多い登山者ほど上俵真布やその他の 登山口を選んでいた。はじめての登山者の 7 割がトムラウシ往復 であるのに対して, トムラウシ山で 2 回以上または大雪山で 4 回 以上の登山経験をもつ登山者は，上俵真布どちらかとその他の登 山口をそれぞれ約 2 割選んでいた。

\section{（2）ルートの選択要因}

登山ルートを選ぶに当たって重視した要因について,「とても重 視した」「やや重視した」と答えた登山者の比率を図 - 2 に示した。 多く選ばれたのは「眺望が良い, 次いで「高山植物・紅葉が美し い「「自然環境が良好に保たれている」といった自然景観に関する もので, 続いて「登山に要する時間が短い」や「登山口に宿・温 泉がある」「登山ルートがガイドブックに紹介されている」「登山 口に十分な駐車スペースがある」といった登山口やルートの利便 性に関するものであった。

これらの 21 の要因について, 因子分析を行った。固有值 1.0 以上で 5 因子が抽出され，バリマックス回転を行った（表 - 3)。 第 I 因子は，「宿泊地に水場がある」「登山ルート上に避難小屋が ある」といった要因から構成されており, 宿泊地・ルートの利便 性を示寸因子と考えられた。第 II 因子は「標高差が少ない」「登 山ルートが歩きやすい」「登山に要する時間が短いといった要因 から構成され，ルートの歩きやすさとアクセス性を示す因子と考 えられた。第III 因子は「登山口に宿・温泉がある」「登山口にト イレある」といった要因から構成され，登山口の利便性示す因子 と考えられた。第 IV 因子は「眺望が良い」「高山植物・紅葉が美 しい」といった要因から構成され，ルートの景観の良さを示寸因 子と考えられた。第 $\mathrm{V}$ 因子は登山ルート上および宿泊地で「他の 登山者が少ない」といった要因から構成され，登山者の少なさを 示寸因子と考えられた。
選択要因の因子毎に，ルート間の因子得点を比較するために分 散分析を行った（図－3）。その結果，「宿泊地・ルートの利便性」 「ルートの歩きやすさとアクセス性」「登山口の利便性」「登山者 の少なさ」の因子得点で有意な差がみられた。「宿泊地・ルートの 利便性」については，トムラウシどちらかと，その他のルートを 選択した登山者がより重視した。「ルートの歩きやすさとアクセ ス性」については，上俵真布を選択した登山者がより重視した。 逆に「登山口の利便性」については，上俵真布でより低く，トム ラウシ往復の登山者がより重視した。「ルートの景観の良さ」につ いては，ルートによる有意差はみられなかった。「登山者の少な さ」については, トムラウシ往復で低く, トムラウシどちらかと 上俵真布の登山者がやや重視した。

\section{4. 考察}

大雪山国立公園卜ムラウシ山を対象に，登山者がルートを選択 する際に重視した要因を把握した。その結果, 登山者がルート選 択の際に重視する要因は, 眺望の良さなどのルートの景観の良さ であり, 次に登山口の利便性, ルートの歩きや寸さであった。景 観の魅力は，大雪山全体を対象にした小林 (1999)5)の結果とも一 致した。Lucas (1990)では，景観の魅力は考慮されておらず，ア クセス性や利便性に加えて, 他の利用者の少なさが重視される結 果が得られているが 6)，本研究では多くの利用者が重視する要因 ではないことが示された。これらの要因は，「宿泊地・ルートの利 便性」や「ルートの歩きや寸さとアクセス性」「登山口の利便性」 「ルートの景観の良さ」「登山者の少なさ」といった因子から構成 された。山本 (2011)は同じ富士山でも登山口によって, 登山者の 属性や登山形態，満足度が異なることを示したが 12)，本研究では ルート間で選択の際に重視される要因が異なることが示された。 トムラウシ山で最も多くの日帰り登山者が利用するトムラウシ温 泉には，公共交通機関や宿泊施設，トイレ，野営場などがあり， 登山口の利便性が高いため選択されていることが分かった。その 一方で, 道央圈からは車で半日程度の距離があるため, 登山口ま での移動も含めると日帰りは難しく, ルートの利便性がやや低く 評価された。利用者が増加していると言われる上俵真布登山口に ついは, 林道の鍵を借りる必要があり, 駐車スペースも少なく, トイレもないため, 登山口の利便性が低く評価された。その一方

表－3 ルートの選択要因の因子分析結果

\begin{tabular}{|c|c|c|c|c|c|c|c|}
\hline 項目 & 第 I 因子 & 第 II 因子 & 第正因子 & 第IV因子 & 第 V 因子 & $\begin{array}{l}\text { 共通性 } \\
\text { 推定値 }\end{array}$ & 平均値 \\
\hline \multicolumn{8}{|l|}{ 宿泊地・ルートの利便性 } \\
\hline 宿泊地に水場がある & 0.858 & 0.011 & -0.085 & 0.054 & 0.151 & 0.769 & 3. 179 \\
\hline 登山ルート上に避難小屋がある & 0.782 & -0.032 & 0.200 & 0.109 & 0.058 & 0.667 & 2. 478 \\
\hline 登山ルート上に野営指定地がある & 0.764 & 0.049 & -0.205 & 0.042 & 0.156 & 0.655 & 2. 869 \\
\hline 登山ルート上に水場がある & 0.753 & 0.196 & -0.121 & 0.109 & 0.136 & 0.651 & 2. 975 \\
\hline 宿泊地にトイレがある & 0.690 & -0.041 & 0.354 & 0.115 & 0.139 & 0.636 & 2. 808 \\
\hline 登山ロに公共交通機関がある & 0.514 & 0.056 & 0.363 & -0.100 & 0.253 & 0.473 & 2. 169 \\
\hline \multicolumn{8}{|l|}{ ルートの歩きやすさとアクセス性 } \\
\hline 標高差が少ない & 0.220 & 0.776 & -0.090 & 0.202 & -0.040 & 0.701 & 2. 898 \\
\hline 登山ルートが歩きやすい & 0.192 & 0.767 & -0.007 & 0.209 & -0.017 & 0.670 & 3. 107 \\
\hline 登山に要する時間が短い & -0.163 & 0.752 & 0.204 & -0.013 & -0.172 & 0.663 & 3. 724 \\
\hline 登山口までの所要時間が短い & 0.010 & 0.718 & 0.211 & -0.105 & 0.262 & 0.640 & 2. 989 \\
\hline 登山口までの道路状況が良い & 0.018 & 0.612 & 0.368 & -0.047 & 0.311 & 0.609 & 2. 818 \\
\hline \multicolumn{8}{|l|}{ 登山口の利便性 } \\
\hline 登山ロに宿・温泉がある & -0.031 & 0.123 & 0.780 & -0.023 & 0.000 & 0.625 & 3.566 \\
\hline 登山ロにトイしがある & 0.039 & 0.095 & 0.776 & 0.117 & 0.077 & 0.633 & 3. 217 \\
\hline 登山ルートがガイドブックに紹介されている & 0.143 & 0.055 & 0.703 & 0.140 & -0.088 & 0.544 & 3. 445 \\
\hline 登山ロに十分な駐車スペースがある & -0.173 & 0.437 & 0.524 & 0.075 & 0.071 & 0.506 & 3. 275 \\
\hline \multicolumn{8}{|l|}{ ルートの景観の良さ } \\
\hline 眺望が良い & 0.057 & 0.051 & 0.094 & 0.839 & 0.037 & 0.721 & 4. 440 \\
\hline 高山植物・紅葉が美しい & 0.112 & 0.074 & 0.043 & 0.838 & 0.073 & 0.728 & 4. 368 \\
\hline 自然環境が良好に保たれている & 0.078 & 0.085 & 0.110 & 0.715 & 0.298 & 0.626 & 4. 166 \\
\hline \multicolumn{8}{|l|}{ 登山者の少なさ } \\
\hline 登山ルート上で他の登山者が少ない & 0.106 & 0.097 & 0.084 & 0.222 & 0.770 & 0.670 & 2. 888 \\
\hline 宿泊地で他の登山者が少ない & 0.388 & 0.076 & -0.022 & 0.094 & 0.748 & 0.725 & 2. 560 \\
\hline 目新しいルートで歩いたことがない。または、少ない & 0.159 & -0.034 & -0.021 & 0.068 & 0.630 & 0.428 & 3. 012 \\
\hline 固有值 & 5.005 & 3.267 & 1.874 & 1.851 & 1.342 & & \\
\hline 累積寄与率 & 0.238 & 0.394 & 0.483 & 0.571 & 0.635 & & \\
\hline
\end{tabular}




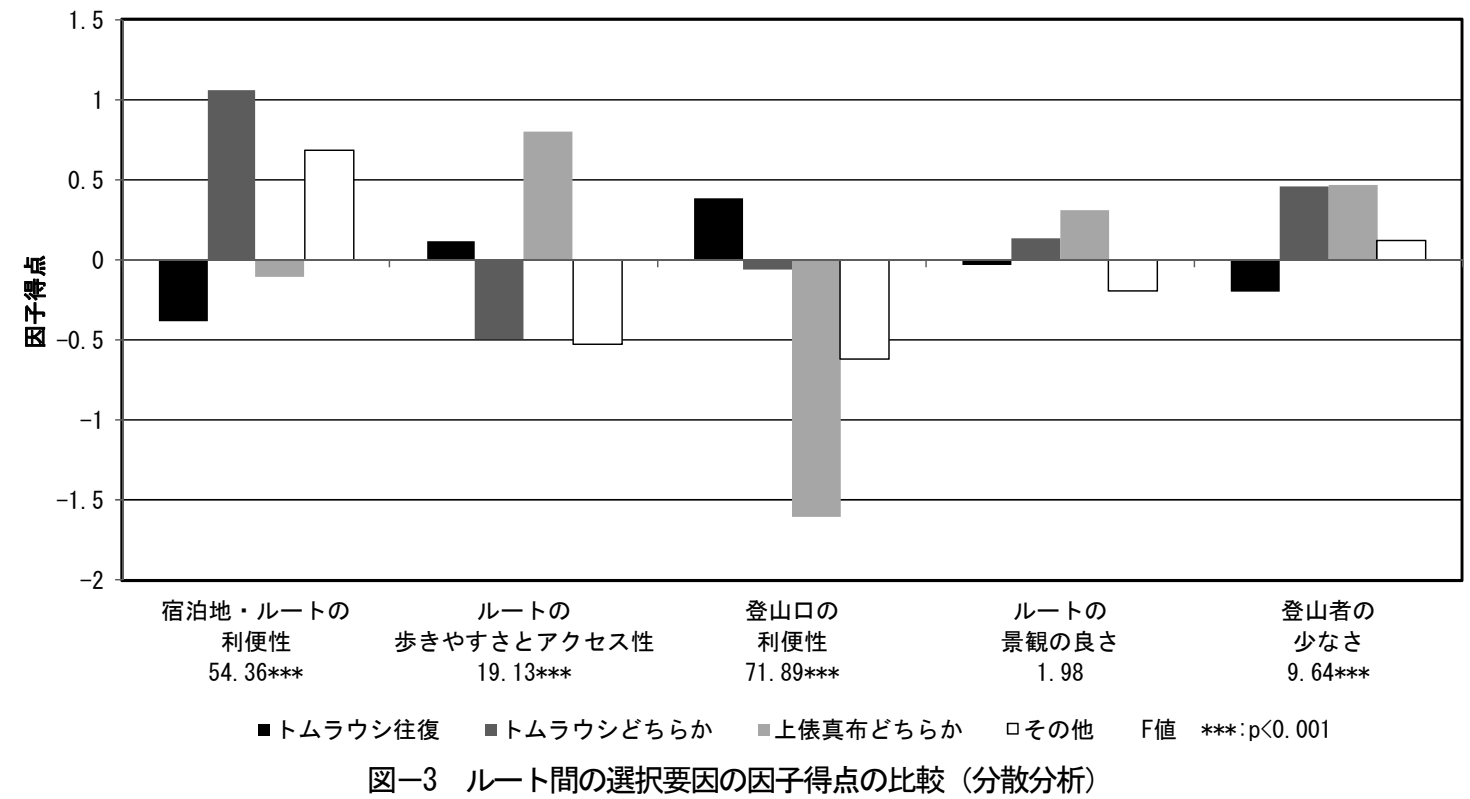

で，道央圈から約 3 時間で到達できるアクセスの良さとなだらか なルートから，ルートの歩きやすさとアクセス性が高く評価され た。登山者の少なさは, トムラウシ温泉往復以外の登山者にやや 重視されており, 混雑を避ける一定の登山者層が存在し（愛甲・ 淺川, 2000；山本，2010）1111)，現状の利用状況に応じて上俵真布 や他の登山口を選択していると推察された。

ルート選択の要因を把握することは，登山者の集中する山岳地 で適正な利用を誘導することにも役立つ。トムラウシ温泉からの ルート上では登山道の侵食も顕著にみられ，南沼野営指定地では 屎尿の散乱と裸地化が進行している (Aikoh, 2008) 3)。これらのイ ンパクトを軽減するために，現状の登山者が重きをおいている登 山口の利便性を低下させることで, 他の登山口への分散をはかる ことも考えられる。その一方で, 上俵真布は他の登山口にくらべ 利便性が低く，登山者の少なさも選択される要因となっている。 より経験のある登山者が，それらを魅力に感じて選択しているこ とも考えられ，登山口とルートの選択から登山者の啫好性や期待 する体験の内容を把握し，それらに配慮した空間整備や管理の方 向性を検討する必要がある (八巻ら, 2003) 10 )

ルートの選択には，登山の日数に加えて，過去の登山経験の影 響もあることが示された。経験の多い利用者はより困難で，管理 があまりされていないルートを選択する傾向がある (McFarlane, et al.1998）7）。経験の多さは，乙の地域を頻繁に訪れる意向の強 さと, 経験に基づく情報量の多さを意味する。経験の多い利用者 ほど，自身の経験やその他の情報にもとづき，より自分の体験に そったルートを選択していると考えられる。逆に, 経験が少なく， 遠方から訪れる登山者には，ルートの選択に参考となる情報を提 供をすることが必要である。その際には，登山者が参考にしてい る情報源, ガイドブックなどの書籍や登山用地図, またインター ネットでの情報提供が有効であることが考えられる。

各登山口の登山者数は同じ方法で集計されておらず，比較がで きない。また，実際のルートの歩きやすさや景観の良さについて も, 客観的に評価し, 登山者の印象との整合性を確認する必要が ある。また, ルート選択の要因については, 登山終了後に回答し てもらったために実際の経験と事前に重視した要因が混同されて いる可能性や，グループで登山した際にルートの決定をしたリー ダーとメンバーの意識の差異も考えられる。より交通機関の発達 した場所では，交通費や待ち時間なども要因として影響する可能 性もあり, 他の地域で研究を行う際には対象地域の状況に対応し た検討が必要である。

\section{引用文献}

1）愛甲哲也・淺川昭一郎 (2000) : 混雑とマナーの悪さに対する 登山者の許容限界とコーピング行動について : ランドスケープ 研究 63 (5), 619-624

2）愛甲哲也・丹下修平・川口恵典 (2004) : 大雪山トムラウシ山 周辺におけるアクセス変化と登山者の意識 : 日本造園学会北海 道支部大会研究・事例報告発表要旨/会報 8, 25-26

3) Aikoh, T. (2008): Monitoring Trampling Impacts from the Disposal of Human Waste at Campsites: Siegrist, D., Clivas, C., Hunziker, M. \& Iten, S.(eds.) Visitor Management in Nature-Based Tourism, 17-24

4) 河井和美 (2008) : 南アルプス南部における山小屋配置が登山 者のルート選択に及ぼす影響: 筑波大学演習林報告 $24,55-107$

5）小林昭裕（1999）：登山にみられる目的地や来訪時期の選択に 関する研究 : ランドスケープ研究 62 (5), 709-714

6) Lucas,R.C. (1990) : How wilderness visitors choose entry points and campsites: USDA Forest Service, INT-428, $12 \mathrm{pp}$.

7) Mcfarlane,B. L., Boxall,P.C. and Watson,O. (1998) : Past experience and behavioral choice among wilderness users : Journal of Leisure Research 30 (2), 195-213

8) 庄子康・柘植隆宏・宮原紀壽 (2005) : 選択型実験による紅葉 期登山者の目的地選択モデルの構築 : ランドスケープ研究 68 (5), 783-786

9）梅沢俊・菅原康彦 (2004) : 最新版北海道夏山ガイド(2) 表大 雪の山々 : 北海道新聞社, $275 \mathrm{pp}$.

10）八巻一成・広田純一 - 小野理 ・ 庄子康 ・土屋俊幸・山口和男 (2003):山岳自然公園における ROS 概念を用いた地域区分手 法 : 日本林学会誌 85(1), 55-62

11）山本清龍 (2010) : 富士登山者の登山口選択と混雑回避 : 環境 情報科学論文集 24, 321-326

12）山本清龍 (2011) : 富士登山者の満足度の登山口別比較 : ラン ドスケープ研究 74(5), 543-546 